\title{
PENGARUH DEBT TO EQUITY RATIO DAN CURRENT RATIO TERHADAP NILAI PERUSAHAAN DENGAN RETURN ON ASSET SEBAGAI VARIABEL INTERVENING
}

\author{
Meliani Imanah \\ e-mail:melyimanah15@gmail.com
}

\author{
Alfinur \\ Supami Wahyu Setiyowati \\ Program Studi Akuntansi, Fakultas Ekonomika dan Bisnis Universitas Kanjuruhan, Malang
}

\begin{abstract}
ABSTRAK
Penelitian ini bertujuan untuk menganalisis pengaruh debt to equity ratio dan current ratio terhadap nilai perusahaan dengan return on asset sebagai variabel intervening pada perusahaan food and beverages yang terdaftar di Bursa Efek Indonesia periode 2016-2018. Penelitian menggunakan data sekunder dari annual report melalui akses ke www.idx.co.id. Data dianalisis menggunakan analisis jalur. Jumlah sampel sebesar 13 perusahaan dan metode pengambilan anggota sampel yang digunakan yaitu purposive sampling. Variabel penelitian ini terdiri dari debt to equity ratio dan current ratio sebagai variabel eksogen, nilai perusahaan sebagai variabel endogen, dan return on asset sebagai variabel intervening. Hasil analisis menunjukkan bahwa debt to equity ratio, current ratio dan return on asset berpengaruh positif terhadap nilai perusahaan. Debt to equity ratio dan current ratio juga berpengaruh positif terhadap return on asset. Berdasarkan hasil analisis jalur implikasi dari penelitian ini yaitu return on asset tidak dapat mempengaruhi hubungan antara debt to equity ratio dan current ratio terhadap nilai perusahaan sehingga dapat memberikan masukan kepada peneliti selanjutnya. Lebih baik menambah periode penelitian dan menggunakan sampel beberapa sektor lain juga dapat menggunakan variabel-variabel lain yang dapat memperkuat hasil penelitian-penelitian sebelumnya.
\end{abstract}

Kata kunci - Debt to Equity Ratio, Current Ratio, Return On Asset, dan Nilai Perusahaan

\begin{abstract}
This study aims to analyze the effect of debt to equity ratio and current ratio on firm value with return on assets as an intervening variable on food and beverages companies listed on the Indonesia Stock Exchange for the period of 2016-2018. The study uses secondary data from the annual report through access to www.idx.co.id. Data were analyzed using path analysis. The total sample of 13 companies and the method of taking sample members used is purposive sampling. The variables of this study consisted of debt to equity ratio and current ratio as exogenous variables,
\end{abstract}


firm value as endogenous variables, and return on assets as intervening variables. The analysis shows that the debt to equity ratio, current ratio and return on assets have a positive effect on firm value. Debt to equity ratio and current ratio also have a positive effect on return on assets. Based on the results of the path analysis of the implications of this research that return on assets can not affect the relationship between debt to equity ratio and current ratio to the firm value so that it can provide input to researchers. It is better to add research periods and use a sample of several other sectors and can also use variables others that can strengthen the results of previous studies.

Keywords - Debt to Equity Ratio, Current Ratio, Return On Assets, and Company Value

\section{PENDAHULUAN}

Kondisi perekonomian saat ini dan banyaknya perusahaan dalam industri menumbuhkan persaingan ketat sehingga mendorong perusahaan untuk meningkatkan kinerja agar tujuan perusahaan tercapai. Selain untuk menghasilkan laba yang maksimal, perusahaan juga mempunyai tujuan utama yaitu memaksimalkan nilai perusahaan. Nilai perusahaan menurut Nurlela dan Ishaluddin (2008) adalah suatu konsep penting bagi pihak investor, karena sebagai indikator bagi pasar menilai perusahaan secara keseluruhan.

Faktor internal yang dapat mempengaruhi nilai perusahaan yaitu Debt to Equty Ratio dan Current Ratio. Menurut Kasmir (2014) Debt to Equity Ratio merupakan rasio keuangan yang dipakai untuk menilai hutang dengan ekuitas perusahaan. Pengertian Current Ratio menurut S. Munawir (2007) merupakan perbandingan antara jumlah aset lancar dengan hutang lancar. Variabel lain yang diduga dapat mempengaruhi nilai perusahaan yaitu Return On Asset karena Return On Asset dapat melihat sejauh mana investasi yang telah ditanamkan mampu memberikan pengembalian keuntungan sesuai yang diharapkan ( Fahmi, 2012).

Penelitian terdahulu Deni dan Yoga (2018) menunjukkan Debt to Equity Ratio (DER) berpengaruh signifikan terhadap nilai perusahaan sedangkan penelitian Rahmad (2018) menunjukkan bahwa DER berpengaruh negatif terhadap nilai perusahaan. Penelitian Zuhria, dkk (2016) menunjukkan bahwa Current Ratio (CR) berpengaruh signifikan terhadap nilai perusahaan sedangkan penelitian Defi (2018) menunjukkan bahwa CR tidak berpengaruh terhadap nilai perusahaan. Penelitian Lintang, dkk (2016) menunjukkan bahwa Return On Asset (ROA) berpengaruh signifikan dan domian terhadap nilai perusahaan sedangkan penelitian Putri dan Welas (2019) menunjukkan bahwa ROA tidak berpengaruh terhadap nilai perusahaan.

Hasil penelitian terdahulu yang berbeda-beda atau tidak konsisten dengan metode analisis regresi berganda membuat peneliti tertarik untuk meneliti variabel-variabel yang dapat mempengaruhi nilai perusahaan dengan menggunakan analisis path atau analisis jalur. Maka penelitian ini bertujuan untuk menganalisis pengaruh Debt to Equity Ratio dan Current Ratio terhadap nilai perusahaan dengan Return On Asset sebagai variabel intervening. 


\section{TINJAUAN PUSTAKA}

\section{Nilai Perusahaan}

Andri dan Hanung (2007) berpendapat bahwa nilai perusahaan adalah nilai jual perusahaan atau nilai tumbuh bagi pemegang saham, nilai perusahaan akan tercermin dari harga pasar sahamnya. Jika perusahaan mengelola perusahaannya dengan baik maka para investor akan tertarik dengan perusahaan tersebut.

\section{Debt to Equity Ratio}

Debt to Equity Ratio (DER) adalah rasio yang digunakan untuk menilai hutang dengan ekuitas (Kasmir, 2014). Rasio ini dihitung dengan cara membandingkan antara seluruh hutang, termasuk hutang lancar dengan seluruh ekuitas. Jika perusahaan dapat mengatur kombinasi antara hutang dengan ekuitas, maka perusahaan dapat memaksimalkan nilai perusahaan.

\section{Current Ratio}

Agus dan Martono (2011) menyatakan Current Ratio merupakan perbandingan antara aset lancar dengan hutang lancar. Pengertian Current Ratio atau rasio lancar yaitu rasio untuk mengukur kemampuan perusahaan membayar kewajiban jangka pendek atau utang yang segera jatuh tempo pada saat ditagih secara keseluruhan.

\section{Return On Asset}

Fahmi (2016) berpendapat bahwa ROA merupakan rasio yang dapat melihat sejauh mana investasi yang telah ditanamkan mampu memberikan pengembalian keuntungan sesuai dengan yang diharapkan. Laba yang tinggi akan lebih menarik perhatian investor dan calon investor agar tetap berinvestasi di perusahaan.

\section{PERUMUSAN HIPOTESIS}

\section{Pengaruh Debt to Equity Ratio Terhadap Nilai Perusahaan}

Debt to Equity Ratio (DER) dihitung dengan cara membandingkan antara seluruh hutang, termasuk hutang lancar dengan seluruh ekuitas. Jika perusahaan dapat mengatur kombinasi antara hutang dengan ekuitas, maka perusahaan dapat memaksimalkan nilai perusahaan. Hutang dan ekuitas dapat mendanai operasi perusahaan sehingga mengandung risiko yang berpengaruh terhadap nilai perusahaan. Pernyataan tersebut diperkuat dalam penelitian Deni dan Yoga (2018) menyatakan bahwa DER berpengaruh signifikan terhadap nilai perusahaan dan penelitian Defi (2018) menyatakan bahwa DER berpengaruh terhadap nilai perusahaan. Dengan demikian, dapat ditentukan suatu hipotesis sebagai berikut :

$\mathrm{H}_{1}$ : Debt to Equity Ratio berpengaruh terhadap nilai perusahaan Pengaruh Current Ratio Terhadap Nilai Perusahaan

Pengertian Current Ratio atau rasio lancar yaitu rasio untuk mengukur kemampuan perusahaan membayar kewajiban jangka pendek atau utang yang segera jatuh tempo pada saat ditagih secara keseluruhan. Pernyataan tersebut diperkuat dalam penelitian Zuhria, dkk (2016) bahwa Current Ratio atau CR berpengaruh signifikan terhadap nilai perusahaan dan penelitian Putri dan Welas (2019) menunjukkan bahwa 
Current Ratio berpengaruh terhadap nilai perusahaan. Dengan demikian, dapat ditentukan suatu hipotesis sebagai berikut :

$\mathrm{H}_{2}$ : Current Ratio berpengaruh terhadap nilai perusahaan Pengaruh Return On Asset Terhadap Nilai Perusahaan

Return on Asset (ROA) merupakan salah satu rasio profitabilitas yang digunakan untuk mengukur kemampuan perusahaan dalam menghasilkan laba bersih berdasarkan tingkat aset tertentu. Laba yang tinggi akan lebih menarik perhatian investor dan calon investor agar tetap berinvestasi di perusahaan.ernyataan tersebut diperkuat dalam penelitian Lintang, dkk (2016) bahwa ROA berpengaruh signifikan dan dominan terhadap nilai perusahaan dan penelitian Defi (2018) menunjukkan bahwa ROA berpengaruh terhadap nilai perusahaan. Dengan demikian, dapat ditentukan suatu hipotesis sebagai berikut:

$\mathrm{H}_{3}$ : Return On Asset berpengaruh terhadap nilai perusahaan Pengaruh Debt to Equity Ratio Terhadap Nilai Perusahaan

Debt to Equity Ratio (DER) adalah rasio yang digunakan untuk menilai hutang dengan ekuitas. Semakin besar rasio DER berarti semakin kecil modal sendiri di dalam menjamin hutang, sehingga bagi perusahaan akan semakin beresiko. Pernyataan tersebut diperkuat dalam penelitian Mahardhika dan Marbun (2016) menunjukkan bahwa Debt to Equity Ratio memberikan pengaruh yang signifikan terhadap Return On Asset dan penelitian Solihin (2019) menunjukkan bahwa Debt

to Equity Ratio berpengaruh signifikan terhadap Return On Asset. Dengan demikan, dapat ditentukan suatu hipotesis sebagai berikut :

$\mathrm{H}_{4}$ : Debt to Equity Ratio berpengaruh terhadap Return On Asset Pengaruh Current Ratio Terhadap Nilai Perusahaan

Current Ratio merupakan perbandingan antara aset lancar dengan hutang lancar. Semakin rendahnya nilai dari Current Ratio, maka akan mengindikasikan ketidakmampuan perusahaan dalam memenuhi kewajiban jangka pendeknya, sehingga hal ini dapat mempengaruhi tingkat rasio Return On Asset. Pernyataan ini diperkuat dalam penelitian Mahardhika dan Marbun (2016) menunjukkan bahwa Current Ratio memberikan pengaruh yang signifikan terhadap Return On Asset. Dengan demikian, dapat ditentutkan suatu hipotesis sebagai berikut :

$\mathrm{H}_{5}$ : Current Ratio berpengaruh terhadap Return On Asset Pengaruh Debt To Equity Ratio Terhadap Nilai Perusahaan dengan Return On Asset Sebagai Variabel Intervening

Debt to Equity Ratio (DER) adalah rasio keuangan yang dipakai untuk menilai utang dengan ekuitas perusahaan. jika perusahaan dapat menjaga proporsi hutangnya maka nilai Return On Asset akan tinggi. Dengan adanya nilai Return On Asset yang tinggi, tujuan utama perusahaan akan tercapai yaitu memaksimalkan nilai perusahaan. Pernyataan tersebut diperkuat dalam penelitian Putri dan Welas (2019) menunjukkan bahwa Debt to Equity Ratio berpengaruh terhadap nilai perusahaan. Selain itu, penelitian 
Lintang, dkk (2016) menunjukkan bahwa Return On Asset berpengaruh secara signifikan dan dominan terhadap nilai perusahaan. Dengan demikian, dapat ditentukan hipotesis sebagai berikut :

\section{$\mathrm{H}_{6}$ : Debt to Equity Ratio berpengaruh terhadap nilai perusahaan dengan Return On Asset sebagai variabel intervening}

\section{Pengaruh Current Ratio Terhadap Nilai Perusahaan dengan Return On Asset Sebagai Variabel Intervening}

Current Ratio atau rasio lancar merupakan perbandingan antara jumlah aktiva lancar dengan hutang lancar. Jika perusahaan dapat efektif dan efisien dalam menggunakan aktiva lancar untuk membayar kewajiban jangka pendeknya, maka hal tersebut dapat berdampak pada pengurangan biaya dan laba pun dapat mengalami pertumbuhan atau peningkatan. Pertumbuhan laba atau yang diukur oleh Return On Asset ini mempunyai hubungan terhadap nilai perusahaan. Nilai Return On Asset yang tinggi akan berdampak terhadap nilai perusahaan. Pernyataan ini diperkuat dalam penelitian Putri dan Welas (2019) menunjukkan bahwa Current Ratio berpengaruh terhadap nilai perusahaan. Selain itu, penelitian Lintang, dkk (2016) menunjukkan bahwa Return On Asset berpengaruh secara signifikan dan dominan terhadap nilai perusahaan. Dengan demikian, dapat ditentukan hipotesis sebagai berikut :

$\mathrm{H}_{7}$ : Current Ratio berpengaruh terhadap nilai perusahaan dengan Return On Asset sebagai variabel intervening

Kerangka konseptual ini dibangun dari penelitian terdahulu dan teori terdahulu yang telah dikemukakan diatas. Maka hubungan antar variabel dalam penelitian ini dapat dinyatakan dalam sebuah kerangka pemikiran sebagai berikut:

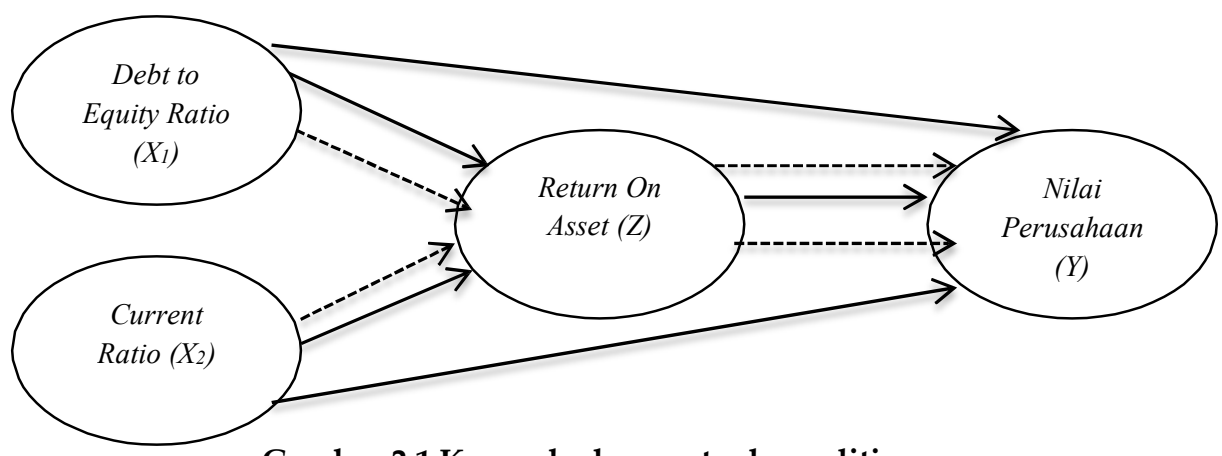

Gambar 2.1 Kerangka konseptual penelitian

\section{METODE PENELITIAN}

Jenis data yang digunakan yaitu data sekunder berupa annual report perusahaan food and beverages periode 2016-2018 yang diperoleh melalui akses internet ke www.idx.co.id. Populasi penelitian yaitu seluruh perusahaan food and beverages yang 
terdaftar di BEI periode 2016-2018 sebesar 25 perusahaan.

Teknik pengambilan sampel menggunakan purposive sampling, yang merupakan penentuan anggota sampel dengan kriteria-kriteria tertentu, yaitu 1) Perusahaan sampel tergolong dalam kelompok food and beverages berdasarkan pengklasifikasian Bursa Efek Indonesia periode 2016- 2018 2) Perusahaan food and beverages yang mempublikasikan laporan keuangan secara berturut- turut selama periode 2016-2018 di BEI. 3) Perusahaan food and beverages yang memperoleh laba periode 2016-2018. Berdasarkan kriteria tersebut, perusahaan yang memenuhi kriteria dan dijadikan sampel penelitian sebesar 13 perusahaan.

\section{Teknik Analisis Data}

Teknik analisis data yang digunakan dalam penelitian ini adalah analisis jalur (path analysis). Pada analisis jalur terdapat variabel yang berperan ganda yaitu sebagai variabel eksogen pada satu hubungan tetapi kemudian menjadi variabel endogen pada hubungan yang lainnya sebagai hubungan kausalitas bertingkat.

$$
\begin{gathered}
Z=P Z X_{1}+P Z X_{2}+e_{1} \\
Y=P Y X_{1}+P Y X_{2}+P Z Y+e_{2}
\end{gathered}
$$

dimana :

$\mathrm{X}_{1}=$ Debt to Equity Ratio

$\mathrm{X}_{2}=$ Current Ratio

$\mathrm{Z}=$ Return On Asset

$\mathrm{Y}=$ Nilai Perusahaan

$\mathrm{P}=$ koefisien regresi yang di

standar e $=$ Error term

\section{HASIL DAN PEMBAHASAN}

\section{Uji Asumsi Klasik}

\section{Jalur X1 dan X2 Terhadap Z}

a) Uji Multikolinearitas

Imam Ghozali (2016) berpendapat bahwa uji multikolineritas memiliki tujuan untuk menguji apakah dalam model regresi ditemukan adanya korelasi antar variabelvariabel bebas. Uji multikolinearitas dapat dilihat dari nilai Tolerance atau Variance Inflation Factor (VIF). Hasil uji VIF variabel X1 = 1,686 dan variabel $\mathrm{X} 2=1,686$ dan menunjukkan bahwa lebih kecil dari 10. Sehingga dinyatakan bahwa tidak terjadi multikolinearitas.

b) Uji Heteroskedastisitas

Tujuan uji heteroskedastisitas untuk menguji apakah dalam metode regresi terjadi ketidaksamaan variance dari residual satu pengamatan ke pengamatan lain, jika variance dari residual satu pengamatan ke pengamatan lain berbeda maka disebut heteroskedastisitas (Imam Ghozali, 2016). Hasil uji heteroskedastisitas menggunakan pendekatan Spearman rank menunjukkan bahwa nilai Sig (2-tailed) dari $\mathrm{X}_{1}=0,658$ dan $\mathrm{X}_{2}=$ 0,143 sehingga nilainya diatas 0,05 . Dengan demikian dapat disimpulkan bahwa tidak terjadi heteroskedastisitas. 
c) Uji Autokorelasi

Uji autokorelasi ini memiliki tujuan untuk mendeteksi apakah model regresi linier memiliki korelasi antara kesalahan pengganggu pada periode tersebut dengan kesalahan pengganggu pada periode sebelumnya. Hasil uji autokorelasi menggunakan pendekatan Durbin Watson menunjukkan bahwa nilainya sebesar 2,098 terletak diantara 1,55-2,46. Dengan demikian dapat disimpulkan bahwa tidak terjadi autokorelasi.

d) Uji Normalitas

Uji normalitas dilakukan untuk menguji apakah dalam model regresi variabel eksogen dan variabel endogen atau keduanya mempunyai ditribusi normal atau tidak (Ghozali, 2016).Hasil pengujian normalitas menggunakan One sample Kolmogorov Smirnov menunjukkan bahwa nilai Sig. (2-tailed) $\mathrm{X}_{1}=0,561, \mathrm{X}_{2}=0,054$, dan $\mathrm{Z}=0,053$ melebihi 0,05 (alpa 5\%). Dengan demikian dapat disimpulkan bahwa data variabel berdistribusi normal.

\section{Jalur X1, X2, dan Z Terhadap Y}

a. Uji Multikolinieritas

Hasil uji multikolinieritas menggunakan pendekatan VIF menunjukkan bahwa nilai variabel $X_{1}=4,190$, variabel $X_{2}=5,946$, dan variabel $Z=2,006$ menunjukkan lebih kecil dari 10. Dengan demikian dapat disimpulkan bahwa tidak terjadi multikolinieritas.

b. Uji Heteroskedastisitas

Hasil heteroskedastisitas menggunakan pendekatan Spearman rank bahwa nilai Sig (2- tailed) dari $X_{1}=0,658, X_{2}=0,143$ dan $Z=0,823$ sehingga nilainya diatas 0,05 . Dengan demikian dapat disimpulkan bahwa tidak terjadi heteroskedastisitas.

c. Uji Autokorelasi

Hasil uji autokorelasi menggunakan pendekatan Durbin Watson menunjukkan bahwa nilainya sebesar 2,057 terletak diantara 1,55 - 2,46 sehingga dapat disimpulkan bahwa tidak terjadi autokorelasi.

d. Uji Normalitas

Hasil uji normalitas menggunakan pendekatan One sample Kolmogorov Smirnov menunjukkan bahwa nilai Sig. (2-tailed) $\mathrm{X}_{1}=0,318, \mathrm{X}_{2}=0,641, \mathrm{Y}=0,972$ dan $\mathrm{Z}=0,472$ melebihi 0,05 (alpa 5\%) sehingga dapat disimpulkan bahwa data variabel berdistribusi normal.

\section{Uji Analisis Jalur}

\section{Jalur X1 dan X2 Terhadap Z}

Nilai koefisien jalur $X_{1} \Rightarrow Z$ bernilai 0,580 dan bertanda positif. Hal ini mengindikasikan bahwa DER berhubungan positif terhadap ROA. Jika DER ditingkatkan nilainya sebesar $1 \%$, maka ROA juga akan meningkat sebesar $0,580 \%$ dengan asumsi variabel lain tidak berubah.

Nilai koefisien jalur $X_{2} \Rightarrow Z$ bernilai 0,696 dan bertanda positif. Hal ini mengindikasikan bahwa $\mathrm{CR}$ berhubungan positif terhadap ROA. Jika CR ditingkatkan nilainya sebesar $1 \%$ maka ROA juga akan meningkat sebesar $0,696 \%$ dengan asumsi variabel lain tidak berubah. 
Selanjutnya di ringkas pada tabel 1 sebagai berikut:

\begin{tabular}{|c|c|c|c|}
\hline Jalur & $\begin{array}{l}\text { Koefisien } \\
\text { Jalur }\end{array}$ & $\begin{array}{l}\text { Nilai } \\
\text { Sig }\end{array}$ & Kesimpulan \\
\hline$X_{1}=\Rightarrow Z$ & 0,580 & 0.003 & Berpengaruh \\
\hline$X_{2}=\Rightarrow Z$ & 0,696 & 0.000 & Berpengaruh \\
\hline \multicolumn{4}{|c|}{$\begin{array}{l}\text { Persamaan jalurnya sebagai } \\
\text { berikut: } Z=P 1 Z X_{1}+P 2 Z X_{2}+e_{1} \\
Z=0,580 X_{1}+0.696 X_{2}+0,833^{*} \\
\left.{ }^{*}\right) e_{1}=V 1-R^{2}\end{array}$} \\
\hline
\end{tabular}

Sumber : Hasil output spss diolah peneliti tahun 2020

\section{Jalur X1, X2, dan Z Terhadap Y}

Nilai koefisien jalur $X_{1} \Rightarrow Y$ bernilai 0,632 dan bertanda positif. Hal ini mengindikasikan bahwa DER berhubungan positif terhadap nilai perusahaan. Jika nilai DER ditingkatkan nilainya sebesar $1 \%$, maka nilai perusahaan juga akan meningkatkan sebesar $0,632 \%$ dengan asumsi variabel lain tidak berubah.

Nilai koefisien jalur $\mathrm{X}_{2} \Rightarrow \mathrm{Y}$ bernilai 0,741 dan bertanda positif. Hal ini mengindikasikan bahwa $C R$ berhubungan positif terhadap nilai perusahaan. Jika $C R$ ditingkatkan nilainya sebesar $1 \%$, maka nilai perusahaan juga akan meningkat sebesar $0,741 \%$ dengan asumsi variabel lain tidak berubah.

Nilai koefisien jalur $Z \Rightarrow Y$ bernilai 0,512 dan bertanda positif. Hal ini mengindikasikan bahwa ROA berhubungan positif terhadap nilai perusahaan. Jika ROA ditingkatkan nilainya sebesar $1 \%$, maka nilai perusahaan juga akan meningkat sebesar 0,512\% dengan asumsi variabel lain tidak berubah. Selanjutnya di ringkas pada tabel 2 sebagai berikut:

\begin{tabular}{|c|c|c|c|}
\hline Jalur & $\begin{array}{c}\text { Koefisien } \\
\text { Jalur }\end{array}$ & $\begin{array}{c}\text { Nilai } \\
\text { Sig }\end{array}$ & Kesimpulan \\
\hline $\mathrm{X}_{1}=\mathrm{Y} \mathrm{Y}$ & 0,632 & 0,002 & Berpengaruh \\
\hline $\mathrm{X}_{2}=\mathrm{Y}$ & 0,741 & 0,002 & Berpengaruh \\
\hline $\mathrm{Z}=\mathrm{Y} \mathrm{Y}$ & 0,512 & 0,000 & Berpengaruh \\
\hline Persamaan jalurnya sebagai & \\
berikut: $\mathrm{Y}=\mathrm{P} \mathrm{YX}_{1}+\mathrm{P}_{\mathrm{Y}} \mathrm{YX} \mathrm{X}_{2}+$ & \\
$\mathrm{P} 5 \mathrm{YZ}+\mathrm{e}_{2}$ & & \\
$\mathrm{Y}=0,632 \mathrm{X}_{1}+0,741 \mathrm{X}_{2}+0,512 \mathrm{Z}+0,539^{*}$ & & \\
${ }^{*} \mathrm{e}_{2}=\mathrm{V} 1-\mathrm{R}^{2}$ & & \\
\hline
\end{tabular}

Sumber : Hasil output spss diolah peneliti tahun 2020

\section{Hasil Uji Hipotesis}

Untuk menguji hipotesis yang diajukan, digunakan Uji $\mathrm{t}$ digunakan untuk mengetahui seberapa jauh pengaruh satu variabel eksogen secara individual dalam menjelaskan variabel endogen. Jika nilai signifikan $t>0,05$ maka hipotesis ditolak. Sebaliknya jika nilai signifikan $\mathrm{t}<0,05$ maka hipotesis diterima yang berarti menunjukkan koefisien regresi signifikan. 
1. Nilai Sig. jalur $X_{1}=>Y$ sebesar 0,002 lebih kecil dari alpa 0,05. Hal ini mengindikasikan bahwa DER berpengaruh terhadap nilai perusahaan. Dengan demikian, hipotesis pertama yang menyatakan bahwa DER berpengaruh terhadap nilai perusahaan diterima.

2. Nilai Sig. jalur $X_{2}=X$ sebesar 0,002 lebih kecil dari alpa 0,05. Hal ini mengindikasikan bahwa CR berpengaruh terhadap nilai perusahaan. Dengan demikian, hipotesis kedua yang menyatakan bahwa CR berpengaruh terhadap nilai perusahaan diterima.

3. Nilai Sig. jalur $Z=\Rightarrow Y$ sebesar 0,000 lebih kecil dari alpa 0,05. Hal ini mengindikasikan bahwa ROA berpengaruh terhadap nilai perusahaan. Dengan demikian, hipotesis ketiga yang menyatakan bahwa ROA berpengaruh terhadap nilai perusahaan diterima.

4. Nilai Sig. jalur $X_{1}=>Z$ sebesar 0,003 lebih kecil dari alpa 0,05. Hal ini mengindikasikan bahwa DER berpengaruh terhadap ROA. Dengan demikian, hipotesis keempat yang menyatakan bahwa DER berpengaruh terhadap ROA diterima.

5. Nilai Sig. jalur $X_{2}=>Z$ sebesar 0,000 lebih kecil dari alpa 0,05. Hal ini mengindikasikan bahwa CR berpengaruh terhadap ROA. Dengan demikian, hipotesis kelima yang menyatakan bahwa CR berpengaruh terhadap ROA diterima.

6. Nilai sig. jalur $X_{1} \Rightarrow Z$ sebesar 0.003 lebih kecil dari alpa 0.05. Hal ini mengindikasikan bahwa DER berpengaruh terhadap ROA. Sementara itu, nilai sig. jalur $Z==>$ Y sebesar

0.000 lebih kecil dari alpa 0.05. Hal ini mengindikasikan bahwa ROA berpengaruh terhadap nilai perusahaan. Dengan demikian, hipotesis keenam yang menyatakan bahwa DER (Debt to Equity Ratio) berpengaruh terhadap nilai perusahaan melalui ROA (Return On Assets) ditolak.

7. Nilai sig. jalur $X_{2} \Rightarrow Z$ sebesar 0.000 lebih kecil dari alpa 0.05. Hal ini mengindikasikan bahwa CR berpengaruh terhadap ROA. Sementara itu, nilai sig. jalur $\mathrm{Z}==>\mathrm{Y}$ sebesar

0.000 lebih kecil dari alpa 0.05. Hal ini mengindikasikan bahwa ROA berpengaruh terhadap nilai perusahaan. Dengan demikian, hipotesis ketujuh yang menyatakan bahwa CR (Current Ratio) berpengaruh terhadap nilai perusahaan melalui ROA (Return On Assets) ditolak.

Untuk mengetahui besar kecilnya pengaruh variabel eksogen terhadap endogen secara langsung maupun melalui variabel intervening dapat dijelaskan sebagai berikut:

1. Pengaruh langsung DER terhadap nilai perusahaan adalah sebesar 0,632. Sedangkan besarnya pengaruh DER terhadap nilai perusahaan jika melalui ROA adalah 0,580 x 0,512 =0,297. Nilai ini lebih kecil dibandingkan dengan pengaruh langsung DER terhadap nilai perusahaan, sehingga apabila perusahaan ingin meningkatkan nilai perusahaan sebaiknya langsung meningkatkan DER. 
2. Pengaruh langsung $C R$ terhadap nilai perusahaan adalah sebesar 0,741. Sedangkan besarnya pengaruh CR terhadap nilai perusahaan jika melalui ROA adalah $0,696 \times 0,512$

$=0,356$. Nilai ini lebih kecil dibandingkan dengan pengaruh langsung $\mathrm{CR}$ terhadap nilai perusahaan, sehingga apabila perusahaan ingin meningkatkan nilai perusahaan sebaiknya langsung meningkatkan CR.

\section{Pembahasan}

\section{Pengaruh Debt to Equity Ratio Terhadap Nilai Perusahaan}

Hasil penelitian ini membuktikan bahwa Debt to Equity Ratio (DER) berpengaruh positif dan signifikan terhadap nilai perusahaan, hasil ini menunjukkan bahwa semakin tinggi nilai DER suatu perusahaan, maka menjadikan perusahaan semakin baik. Jika perusahaan dapat mengatur kombinasi antara hutang dengan ekuitas, maka perusahaan dapat memaksimalkan nilai perusahaan. Dengan demikian DER mempengaruhi nilai perusahaan sehingga investor akan merespon positif perusahaan dan akan tertarik untuk menanamkan saham pada perusahaan tersebut. Banyaknya investor yang menanamkan saham pada perusahaan akan membuat peningkatan harga saham sehingga berakibat pada naiknya nilai perusahaan.

\section{Pengaruh Current Ratio Terhadap Nilai Perusahaan}

Hasil penelitian ini membuktikan bahwa Current Ratio (CR) berpengaruh positif dan signifikan terhadap nilai perusahaan. Current Ratio (CR) merupakan salah satu rasio likuiditas dimana jika CR semakin tinggi akan menunjukkan bahwa bahwa perusahaan mampu membayar hutang-hutang jangka pendeknya karena perusahaan mempunyai nilai aset lancar lebih besar dibanding dengan nilai hutang lancarnya. Hal ini akan memberikan sinyal positif kepada investor untuk menginvestasikan dananya karena semakin besar rasio ini maka akan semakin efisien perusahaan dalam menggunakan aset lancar perusahaan dimana aset lancar berarti kekayaan atau uang tunai yang dapat digunakan untuk menutupi utang-utang perusahaan. Jika perusahaan mampu menutupi hutang-hutangnya maka akan berdampak pada minat investor untuk berinvestasi sehingga nilai perusahaan akan meningkat.

\section{Pengaruh Return On Asset Terhadap Nilai Perusahaan}

Hasil penelitian ini membuktikan bahwa Return On Asset (ROA) berpengaruh positif dan signifikan terhadap nilai perusahaan, hasil ini menunjukkan bahwa semakin tinggi ROA suatu perusahaan maka menjadikan perusahaan itu jauh lebih baik. ROA yang positif menunjukkan bahwa dari total aset yang dipergunakan untuk operasi perusahaan mampu memberikan laba bagi perusahaan. Jika laba perusahaan semakin tinggi akan memberikan nilai tambah kepada nilai perusahaan. Perusahaan yang memiliki nilai perusahaan yang tinggi akan lebih menarik perhatian investor dan calon investor agar tetap berinvestasi di dalam perusahaan tersebut. 
Pengaruh debt to equity ratio dan current ratio terhadap nilai perusahaan dengan return on asset sebagai variabel intervening

\section{Pengaruh Debt to Equity Ratio Terhadap Return On Asset}

Hasil penelitian ini membuktikan bahwa Debt to Equity Ratio (DER) berpengaruh positif dan signifikan terhadap Return On Asset (ROA). DER merupakan pendanaan yang berasal dari hutang dimana hutang tersebut digunakan untuk biaya operasional dalam meningkatkan keuntungan. Ini berarti bahwa jika DER meningkat maka ROA juga akan meningkat. Semakin tinggi DER akan semakin besar juga kepercayaan dari pihak luar karena memungkinkan meningkatkan kinerja perusahaan dengan modal yang besar maka kesempatan untuk meraih tingkat keuntungan juga besar. Hal ini menunjukkan dengan semakin meningkatnya hutang perusahaan juga meningkatkan kemampuan perusahaan untuk menghasilkan laba agar perusahaan dapat memenuhi kewajibannya membayar hutang.

\section{Pengaruh Current Ratio Terhadap Return On Asset}

Hasil penelitian ini membuktikan bahwa Current Ratio (CR) berpengaruh positif dan signifikan terhadap Return On Asset (ROA). Jika Current Ratio meningkat Return On Asset juga akan meningkat karena disebabkan dengan menambahnya hutang dan laba yang didapat bisa lebih efektif dalam meminimalisir hutang pada perusahaan dan juga pada laba itu sendiri. Dapat dikatakan pula kemampuan perusahaan untuk membayar hutang jangka pendek dan membayar hutang jangka panjang sehingga meningkatkan laba perusahaan.

\section{Pengaruh Debt to Equity Ratio terhadap Nilai Perusahaan dengan Return On Asset sebagai Variabel Intervening}

Hasil penelitian ini membuktikan bahwa Debt to Equity Ratio tidak berpengaruh terhadap nilai perusahaan dengan Return On Asset (ROA) sebagai variabel intervening. Hal ini berarti dengan adanya ROA tidak mempengaruhi DER dalam meningkatkan nilai perusahaan. Artinya bahwa hutang yang dapat meningkatkan laba perusahaan tidak akan mampu memberikan pengaruh yang lebih terhadap nilai perusahaan karena ROA tidak mampu memediasi pengaruh DER terhadap nilai perusahaan. Dengan demikian untuk meningkatkan nilai perusahaan tidak dapat meningkatkan DER dimana peningkatan DER tersebut tidak dapat meningkatkan ROA yang secara tidak langsung tidak dapat meningkatkan nilai perusahaan lebih tinggi.

\section{Pengaruh Current Ratio terhadap Nilai Perusahaan dengan Return On Asset sebagai Variabel Intervening}

Hasil penelitian ini membuktikan bahwa Current Ratio tidak berpengaruh terhadap nilai perusahaan dengan Return On Asset (ROA) sebagai variabel intervening. Hal ini berarti dengan adanya ROA tidak mempengaruhi CR dalam meningkatkan nilai perusahaan. Artinya kondisi baik pada aset lancar yang dapat meningkatkan laba perusahaan tidak akan mampu memberikan pengaruh yang lebih terhadap nilai perusahaan karena ROA tidak mampu memediasi pengaruh CR terhadap nilai perusahaan. Dengan demikian untuk meningkatkan nilai perusahaan tidak dapat meningkatkan $\mathrm{CR}$ dimana peningkatan $\mathrm{CR}$ tersebut tidak dapat meningkatkan ROA yang secara tidak langsung tidak dapat meningkatkan nilai perusahaan lebih tinggi.

KESIMPULAN

Copyright (C JRMA 2020 e-ISSN. 2715-7016

Hal | 11 
Pengaruh debt to equity ratio dan current ratio terhadap nilai perusahaan dengan return on asset sebagai variabel intervening

Berdasarkan hasil analisis dan penjelasan yang telah dilakukan, dapat disimpulkan bahwa debt to equity ratio, current ratio dan return on asset berpengaruh positif terhadap nilai perusahaan. Debt to equity ratio dan current ratio juga berpengaruh positif terhadap return on asset. Berdasarkan hasil analisis jalur return on asset tidak dapat mempengaruhi hubungan antara debt to equity dan current ratio terhadap nilai perusahaan.

Bagi peneliti selanjutnya yang tertarik untuk meneliti lebih lanjut mengenai nilai perusahaan akan lebih baik jika penelitian selanjutnya sebaiknya menambah periode penelitian dan sampel yang digunakan ditambah dan diperluas ke beberapa sektor perusahaan sehingga menghasilkan informasi yang lebih akurat lagi. Selain itu, perlu adanya penelitian yang menggunakan variabel-variabel lain yang menggambarkan pengaruhnya lebih relevan terhadap nilai perusahaan sehingga dapat memperkuat hasil penelitian-penelitian yang telah dilakukan sebelumnya.

\section{DAFTAR PUSTAKA}

A.Ross, Stephen, dkk. 2009. Pengantar Keuangan Perusahaan 1. Jakarta: Salemba Empat

Andri dan Hanung. 2007. Analisis Faktor-Faktor yang Mempengaruhi Kualitas Laba dan Nilai Perusahaan. Simposium Nasional Akuntansi X Makassar, 26-28 Juli (online), (https://datakata.files.wordpress.com), diakses tanggal 30 Oktober 2019

Defi. 2018. Pengaruh Debt to Equity Ratio, Current Ratio, Return On Asset, Pertumbuhan Penjualan dan Dividen Payout Ratio Terhadap Nilai Perusahaan Pada Perusahaan Manufaktur Yang Terdaftar Di Bursa Efek Indonesia (BEI) Periode Tahun 2013-2016 (online), (repository.umrah.ac.id), diakses tanggal 18 Oktober 2019

Deni dan Yoga. 2018. Pengaruh Debt To Equity Ratio (DER) dan Deviden Payout Ratio (DPR) Terhadap Nilai Perusahaan Pada Perusahaan Manufaktur Sektor Hasil Industri Untuk Konsumsi Yang Terdaftar di BEI Tahun 2012-2017. Jurnal Manajemen 7 (1) (online), (e-jurnal.lppmunsera.org), diakses tanggal 18 Oktober 2019

Fahmi, Irham. 2012. Analisis Kinerja Keuangan. Bandung: Alfabeta

Fahmi, Irham. 2015. Analisis Laporan Keuangan, Cetakan kelima. Bandung: CV Alfabeta

Ghozali. 2016. Aplikasi Analisis Multivariate Dengan Program IBM SPSS. Semarang: Badan

Penerbit Universitas Diponegoro

Hanafi, Mamduh M, Abdul Halim. 2012. Analisis Laporan Keuangan, Edisi pertama. Yogyakarta: UPP STIM YKPN

Harahap, S.S. 2013. Analisis Kritis atas Laporan Keuangan. Jakarta: Raja Grafindo Persada

Hery. 2015. Analisis Laporan Keuangan, Pendekatan Rasio Keuangan, edisi pertama. Yogyakarta: CAPS (Center for Academic Publishing Service)

Kasmir, 2014. Analisis Laporan Keuangan. Edisi Satu. Cetakan Ketujuh. Jakarta: PT Raja Grafindo Persada

Lintang, dkk. 2017. Analisis Pengaruh ROA, ROE, NPM Terhadap Nilai Perusahaan Pada PT. Garuda Indonesia (Persero) Tbk (online), (https://fe.ubhara.ac.id), diakses 
Pengaruh debt to equity ratio dan current ratio terhadap nilai perusahaan dengan return on asset sebagai variabel intervening tanggal 18 Oktober 2019

Mahardhika, P. Dan Marbun. 2016. Pengaruh Current Ratio dan Debt To Equity Ratio terhadap Return On Assets, Jurnal Widyakala, Vol.3, Maret 2016, (online), (https://ojs.upj.ac.id), diakses tanggal 18 Oktober 2019

Munawir. 2007. Analisis Laporan Keuangan. Yogyakarta: Edisi Empat, Liberty

Nurlela, Rika dan Islahuddin. 2008. Pengaruh Corporate Social Responsibility terhadap Nilai Perusahaan dengan Prosentase Kepemilikan Manajerial sebagai Variabel Moderating. Simposium Nasional Akuntansi XI. Pontianak (online), (https://stiepena.ac.id), diakses tanggal 30 Oktober 2019

Putri dan Welas. 2019. Pengaruh Current Ratio, Return On Asset, Total Asset Turnover dan Debt To Equity Ratio Terhadap Nilai Perusahaan (Studi Empiris pada Perusahaan Manufaktur Sub Sektor Properti dan Real Estate Yang Terdaftar di Bursa Efek Indonesia Periode 2015-2017). Jurnal Akuntansi dan Keuangan, Vol.8 No.1, 1 April 2019 (online), (journal.budiluhur.ac.id), diakses tanggal 18 Oktober 2019

Solihin, Dede.2019. Pengaruh Current Ratio dan Debt to Equity Ratio terhadap Return On Asset (ROA) Pada PT Kalbe Farma, Tbk, Kreatif Jurnal Ilmiah Prodi Manajemen Universitas Pamulang, Volume 7 No.1, Juni 2019 (online), (http://openjournal.unpam.ac.id), diakses tanggal 17 Desember 2019

Sunyoto, D. 2013. Dasar-Dasar Manajemen Keuangan Perusahaan, Cetakan Pertama. Yoyakarta: Center for Academic Publishing Service www.idx.co.id, diakses tanggal 5 November 2019

Zuhria, dkk. 2016. Pengaruh Current Ratio, Ukuran Perusahaan, Struktur Modal, dan ROE

Terhadap Nilai Perusahaan Farmasi Yang Terdaftar Di Bursa Efek Indonesia Periode 2011-2014, Jurnal Berkala Ilmiah Efisiensi, Vol.16 No.03, Tahun 2016 (online), (https://ejournal.unsrat.ac.id), diakses tanggal 12 Oktober 2019 